\title{
Immunological aspect of non-obese diabetic mice: immune islet cell-killing mechanism and cell-mediated immunity
}

\author{
T. Maruyama, I. Takei, M. Taniyama, K. Kataoka and S. Matsuki \\ Department of Internal Medicine, School of Medicine, Keio University, Tokyo, Japan
}

Summary. The non-obese diabetic mouse is thought to be one of the best available animal models for human Type 1 (insulindependent) diabetes. By ${ }^{51} \mathrm{Cr}$ release assay we investigated cell-mediated cytotoxicity to the islet cells of $\mathrm{Balb} / \mathrm{C}$ mice, natural killer activity, and antibody-dependent cell-mediated cytotoxicity activity of spleen lymphocytes from pre-diabetic non-obese diabetic mice. The cell-mediated cytotoxicity to islet cells of non-obese diabetic mice was significantly higher than that of control ICR mice. In contrast, natural killer and antibody-dependent cell-mediated cytotoxicity activities of the spleen cells from the non-obese diabetic mice were signifi- cantly lower than those of ICR mice spleen cells. These results suggest that lymphocytes from non-obese diabetic mice were sensitized to the antigen of islet cells and that the non-specific cellular immunity of non-obese mice was reduced. They suggest also that this immune islet cell-killing mechanism may play an important role in the pathogenesis of diabetes in nonobese diabetic mice.

Key words: Non-obese diabetic mice, cell-mediated cytotoxicity, islet cells, natural killer activity, antibody-dependent cell-mediated cytotoxicity.
The non-obese diabetic (NOD) mouse is thought to be one of the best available animal models for human Type 1 diabetes because it develops ketosis-prone diabetes after the appearance of insulitis [1,2]. It has been reported that islet cell cytoplasmic antibodies, islet cell surface antibodies and many cellular and humoral immune abnormalities were found before the onset of diabetes in NOD mice [3-5]. To elucidate the pathogenesis of human Type 1 diabetes, we investigated the cellular immunity of the pre-diabetic NOD mouse, including the immune islet cell killing mechanism, natural killing activity and antibody-dependent cell-mediated cytotoxicity (ACDD) activity of the spleen cells and compared the results with those for control ICR (JCL-ICR) mouse, which is the original strain of the NOD mouse.

\section{Materials and methods}

\section{Mice}

Five 8-week old female NOD and five age- and sex-matched ICR mice were studied. The NOD mice were obtained from Dr Tochino, Aburabi Laboratories, Shionogi, Japan and the ICR mice from Clea Japan Inc., Tokyo, Japan.

\section{Isolation of spleen cells and microscopic examination of pancreases}

The mice were killed by aspirating blood from the heart under ether anaesthesia and the spleen and pancreas were removed aseptically. The spleen was minced with scissors and passed through a stainless steel mesh. It was then washed three times by centrifugation with Hank's balanced salt solution ( $1000 \mathrm{rev} / \mathrm{min}$ for $5 \mathrm{~min})$. After washing, the spleen cells were resuspended in RPMI-1640 medium supplemented with $10 \%$ heat-inactivated fetal calf serum, and used for effector cells. The pancreas was fixed in Bouin's solution, embedded in paraffin, stained with haematoxylin-eosin and examined by light microscopy.

\section{Cell-mediated cytotoxicity to islet cells}

$\mathrm{Balb} / \mathrm{C}$ mouse islets were separated from the collagenase-digest by Percoll-gradient centrifugation and then individually chosen with the aid of a stereomicroscope [6]. The islets were suspended in $1 \mathrm{ml}$ RPMI-1640 medium supplemented with $1 \%$ bovine serum albumin and $2 \mathrm{mmol} / \mathrm{I}$ EGTA, and were dissociated into a single cell suspension by aspiration of the islet mixture five to ten times through a Pasteur pipette with a constricted tip. The cells were resuspended in RPMI-1640 medium supplemented with $10 \%$ heat-inactivated fetal calf serum and cultured overnight at $37^{\circ} \mathrm{C}$ in $5 \% \mathrm{CO}_{2}$. Suspensions of these islet cells were incubated at $37^{\circ} \mathrm{C}$ for $60 \mathrm{~min}$ in $1 \mathrm{ml}$ RPMI- 1640 medium supplemented with $10 \%$ heat-inactivated fetal calf serum and $0.05 \mathrm{mCi} \mathrm{Na}_{2}{ }^{51} \mathrm{CrO}_{4}$ (Daiichi Radioisotope Laboratories, Tokyo, Japan). After incubation, the cells were washed three times by centrifu- 
Table 1. Characteristics of the mice used in this study and the results of cytotoxicity to islet cells, natural killer and antibody-dependent cell-mediated cytotoxicity activities

\begin{tabular}{llll}
\hline & NOD mice & ICR mice & $p$ \\
\hline Body weight $(\mathrm{g})$ & $20.4 \pm 1.62$ & $28.6 \pm 1.02$ & $<0.001$ \\
Urinary glucose & negative & negative & \\
Insulitis & $5 / 5$ & $0 / 5$ & \\
Number of spleen cells & $6.51 \pm 2.18$ & $10.7 \pm 1.48$ & $<0.001$ \\
$\quad\left(\times 10^{7} /\right.$ spleen $)$ & & & \\
$\quad$ Number of spleen cells $/$ & $2.44 \pm 0.10$ & $3.54 \pm 0.60$ & $<0.01$ \\
$\quad$ body weight $\left(\times 10^{6} / \mathrm{g}\right)$ & & & \\
Cytotoxicity to islet cells $(\%)$ & $9.8 \pm 3.0$ & $2.8 \pm 3.7$ & $<0.05$ \\
Natural killer activity $(\%)$ & $6.18 \pm 4.3$ & $13.6 \pm 3.6$ & $<0.05$ \\
ADCC activity $(\%)$ & $16.2 \pm 1.3$ & $26.8 \pm 4.4$ & $<0.01$ \\
\hline
\end{tabular}

Results expressed as mean \pm SD. $p$ values are calculated by Student's t-test

gation ( $450 \mathrm{rev} / \mathrm{min}$ for $20 \mathrm{~min}$ ) in RPMI-1640 medium supplemented with $10 \%$ heat-inactivated fetal calf serum, and used for target cells. The suspensions of $1 \times 10^{4}$ target cells were incubated at $37^{\circ} \mathrm{C}$ in $5 \%$ $\mathrm{CO}_{2}$ for $5 \mathrm{~h}$ with $1 \times 10^{6}$ effector cells. After incubation, released ${ }^{51} \mathrm{Cr}$ was counted in a well-type gamma counter (Aloka, Tokyo, Japan). The results were expressed as specific ${ }^{51} \mathrm{Cr}$ release:

specific release $=\frac{\text { experimental release-spontaneous release }}{\text { maximum release-spontaneous release }} \times 100$ $(\%)$. The maximum ${ }^{51} \mathrm{Cr}$ release was the release when incubated with $5 \%$ Triton X-100, and spontaneous release was that found on incubation with medium alone.

\section{Natural killer activity}

Chang-liver cells (Flow Laboratories, Virginia, USA) were labelled by $\mathrm{Na}_{2}{ }^{51} \mathrm{CrO}_{4}$ using the same method described for cell-mediated cytotoxicity to islet cells, and used for target cells. The suspensions of $1 \times 10^{4}$ target cells were incubated at $37^{\circ} \mathrm{C}$ in $5 \% \mathrm{CO}_{2}$ for $10 \mathrm{~h}$ with $1 \times 10^{6}$ effector cells, and the results were obtained by the same method as for cell-mediated cytotoxicity.

\section{Antibody-dependent cell-mediated cytotoxicity activity}

Chicken red blood cells (Jimro, Takasaki, Japan) were incubated at $37^{\circ} \mathrm{C}$ for $60 \mathrm{~min}$ in $1 \mathrm{ml}$ Hank's balanced salt solution supplemented with $0.05 \mathrm{mCi} \mathrm{Na}_{2}{ }^{51} \mathrm{CrO}_{4}$, washed three times by centrifugation (1000 rev/min for $10 \mathrm{~min}$ ) in Hank's balanced salt solution and used for target cells. Suspensions of $1 \times 10^{5}$ target cells were incubated at $37^{\circ} \mathrm{C}$ in $5 \% \mathrm{CO}_{2}$ for $18 \mathrm{~h}$ with $1 \times 10^{7}$ effector cells, $1: 400$ diluted antichicken red blood cells IgG and $1 \times 10^{7}$ sheep red blood cells. After incubation, released ${ }^{51} \mathrm{Cr}$ was counted by a well-type gamma counter and specific release was calculated using the same formula described above.

\section{Results}

Insulitis was found in all NOD mice, but not in ICR mice. Urinary glucose was negative in both strains of mice. The spleens of the NOD mice contained $6.51 \pm$ $2.18 \times 10^{7}$ cells $/$ spleen $($ mean \pm SD) which was significantly lower than in ICR mice $\left(10.7 \pm 1.48 \times 10^{7} /\right.$ spleen; $p<0.001)$. When expressed as the number of spleen cells/g body weight, the spleen cell count also was lower in the NOD mice $\left(2.44 \pm 0.1 \times 10^{6} / \mathrm{g}\right)$ than in ICR mice $\left(3.54 \pm 0.6 \times 10^{6} / \mathrm{g} ; p<0.01\right)$.

The cell-mediated cytotoxicity of NOD mice (specific ${ }^{51} \mathrm{Cr}$ release: $9.8 \pm 3.0 \%$; mean $\pm \mathrm{SD}$ ) was significantly higher than that of ICR mice $(2.8 \pm 3.7 \%$; $p<$ $0.05)$. In contrast natural killer $(6.18 \pm 4.3 \%)$ and $\mathrm{ADCC}$ $(16.2 \pm 1.3 \%)$ of the spleen cells from the NOD mice were significantly lower than those of the ICR mice $(13.6 \pm 3.6 \%$ and $26.8 \pm 4.4 \%$, respectively; $p<0.05$ and $p<0.01$; Table 1 ).

\section{Discussion}

Our results demonstrate that spleen cells from NOD mice were cytotoxic to $\mathrm{Balb} / \mathrm{C}$ mouse islet cells. On the other hand, the number of spleen cells, natural killer and ADCC activities of NOD mice were lower than those of control ICR mice. These results suggest that cell-mediated cytotoxicity in NOD mice is specific to islet cells and that the non-specific cellular immunity of NOD mice is weak. It has been reported that both islet cell cytoplasmic antibodies and islet cell surface antibodies were recognized in pre-diabetic NOD mice [3, 4], so NOD mice were thought to be sensitized to the antigen of islet cells. Thus, there are two possible modes of cell-mediated cytotoxicity to islet cells. One is cytotoxicity due to sensitized T-lymphocytes and the other antibody-dependent cell-mediated cytotoxicity which is initiated by attachment of islet cell surface antibodies to $F_{c}$ receptor-bearing lymphocytes. It has been reported that lymphocytes from patients with insulin-dependent diabetes destroy insulinoma cells and cultured rat islet cells $[7,8]$ and that islet cell surface antibody-positive sera show cytotoxicity to islet cells in the presence of complement or lymphocytes [9-11]. Our results support these studies and suggest that these immune islet cellkilling mechanisms exist before the onset of diabetes and that they may play an important role in the pathogenesis of insulin-dependent diabetes.

Acknowledgements. We are grateful to Dr. Å.Lernmark for his kind advice, Mrs. S. Kawakami and Mr. K. Seki who prepared the microscope samples, and Ms. B. Levine for help with the manuscript.

\section{References}

1. Makino S, Kunimoto K, Muraoka Y, Mizushima Y, Katagiri K, Tochino $Y(1980)$ Breeding of a non-obese diabetic strain of mice. Exp Anim 29:1-13

2. Tochino Y, Kanaya T, Makino S (1982) Genetics of NOD mice. In: Mimura G, Baba S, Goto Y, Köbberling J (eds) Clinico-genetic genesis of diabetes mellitus. Excerpta Medica, Amsterdam, pp 285-291

3. Toyota T, Kataoka S, Sato J, Fujita H, Hayashida Y, Goto Y, Kumagai $K$ (1982) Islet-cell antibody and immunologic aspect of NOD mice. In: Mimura G, Baba S, Goto Y, Köbberling J (eds) Clinico-genetic genesis of diabetes mellitus. Excerpta Medica, Amsterdam, pp 185-192 
4. Takei I, Maruyama T, Taniyama M, Maruyama H, Kataoka K, Ishii T (1982) Islet-cell surface antibodies and lymphocyte antibodies in the spontaneously diabetic NOD mouse. In: Alberti KGMM, Ogada T, Aluoch JA, Mngola EN (eds) 11th Congress of the International Diabetes Federation, Nairobi, p 204 (Abstract)

5. Kataoka S, Satoh J, Fujita H, Toyota T, Suzuki R, Itoh K, Kumagai K (1983) Immunologic aspect of nonobese diabetic (NOD) mouse. Abnormalities of cellular immunity. Diabetes 32: 247-253

6. Lernmark Å, Kanatsuna T, Potzelt C, Diakoumis K, Carroll R, Rubenstein AH, Steiner DF (1980) Antibodies directed against the pancreatic islet cell membrane. Diabetologia 19:445-451

7. Huang SW, Maclaren NK (1976) Insulin-dependent diabetes: a disease of autoaggression. Science 192: 64-66

8. Charles MA, Suzuki M, Waldeck N, Dodson LE, Slater L, Ong K, Kershner A, Buckingham B, Golden M (1983) Immune islet killing mechanisms associated with insulin-dependent diabetes: in vitro expression of cellular and antibody-dependent islet cell cytotoxicity in humans. J Immunol 130: 1189-1194

9. Dobersen MN, Scharf JE, Ginsberg-Fellner F, Notkins AL (1980) Cytotoxic autoantibodies to beta cells in the serum of patients with insulin-dependent diabetes mellitus. N Engl J Med 303: 1493-1498

10. Kanatsuna T, Lernmark $\AA$, Rubenstein $A H$, Steiner DF (1981) Block in insulin release from column-perifused pancreatic $\beta$-cell induced by cell surface antibodies and complement. Diabetes 30 : $231-234$

11. Maruyama T, Takei I, Matsuba I, Tsuruoka A, Taniyama M, Ikeda Y, Kataoka K, Abe M, Matsuki S (1984) Cell-mediated cytotoxic islet cell surface antibodies to human pancreatic beta cells. Diabetologia 26: 30-33

Dr. T. Maruyama

Department of Internal Medicine

School of Medicine

Keio University

35 Shinanomachi

Shinjuku-ku

Tokyo 160

Japan 